\title{
Effects of Natural Disaster on Rice Production at Farm Level: New Evidence from Vietnam
}

\author{
Hong - Ron Nguyen ${ }^{1}$, Quang - Thanh $\mathrm{Ngo}^{2}$, Ngoc - Danh Nguyen ${ }^{3}$ \\ ${ }^{1}$ University of Finance - Marketing, Ho Chi Minh City, Vietnam \\ 2 Southern Center of Agricultural Policy and Strategy, Institute of Policy and Strategy for Agriculture \\ and Rural Development, Ho Chi Minh City, Vietnam \\ ${ }^{3}$ School of Economics, University of Economics Ho Chi Minh City, Ho Chi Minh City, Vietnam
}

\begin{abstract}
The current study uses a unique balanced panel of 3,922 households between 2008 and 2010 to examine the extent to which rice production in Vietnam is affected by natural disasters and how coping strategies lessen the negative effects of natural disaster, using a fixed effects model that controls for time invariant farm heterogeneity. With regard to natural disaster, we find evidence of the negative inter-temporal occurrence and negative inter-temporal severity effects, and the negative current occurrence one as well. With regard to coping strategies, we find various evidence of current, inter-temporal coping-occurrence and copingseverity effects, depending on kinds of coping strategies.
\end{abstract}

\section{Keywords}

Current and inter-temporal occurrence effects, current and inter-temporal severity effects, current and intertemporal coping-occurrence effects, current and inter-temporal coping-severity effects, natural disaster, rice production, Vietnam.

Nguyen, H.-R., Ngo, Q.-T. and Nguyen, N.-D. (2018) "Effects of Natural Disaster on Rice Production at Farm Level: New Evidence from Vietnam", AGRIS on-line Papers in Economics and Informatics, Vol. 10, No. 1, pp. 37-49. ISSN 1804-1930. DOI 10.7160/aol.2018.100104.

\section{Introduction}

Agriculture is inherently sensitive to climate conditions and is among the sectors most vulnerable to natural disaster. In simple terms, according to Sivakumar (2005), a natural disaster is a natural event with catastrophic consequences for living things in the vicinity. Natural disasters can be classified into hydro-meteorological and geophysical disasters (Sivakumar, 2005), in which the former includes landslides, droughts, extreme temperatures and heat waves, floods, tropical cyclones, windstorms; and others (insect infestation and waves/surges), and the latter include earthquakes and volcanic eruptions (IFRC/RCS, 2003).

In this paper, we explore the extent to which rice production in Vietnam is affected by natural disasters such as flood, drought, typhoon and landslides and how coping strategies lessen the negative effects of natural disaster. Our primary hypothesis is that natural disasters have negative impacts on rice production and coping strategies can lessen the negative effects of natural disaster to a certain extent. While many empirical studies have done so far on the effects of natural disaster, either at nation, region, community, household, and individual level or sector and crop level, such as Blaikie et al. (2014), Loayza et al. (2012), Kaplan (2010), Ludwig et al. (2007), De Haen and Hemrich (2007), Sawada (2007), Alderman et al. (2006), Toya and Skidmore (2005), Sivakumar (2005), Fothergill and Peek (2004), Das et al. (2003), Pelling et al. (2002), Jacoby and Skoufias (1997), Deaton (1997), Benson (1997), and Long (1978), and coping strategies as well such as Davies et al. (2013), Briguglio et al. (2009), Fafchamps (2009), Greiving et al. (2006), Rose (2004), Bruneau et al. (2003), and Rosenzweig and Wolpin (1993), little is known about the effects of natural disaster on rice production at the farm level (with an exceptional research of Israel and Briones (2012) for the case of the Philippnies at the provincial level). This is mainly due to a lack of suitable information.

The study focuses on the impact of natural disaster on rice production at the farm level in Vietnam for several reasons: Firstly, paddy rice (referred as rice in this paper for simplification) has played 
an important role in food security, agriculture, and rural development in the world in general and in Vietnam in specific. In Vietnam, rice accounts for more than three-quarters of the country's total annual harvested agricultural area and employs about two-thirds of the rural labor force. Because the scope of expanding arable land to increase production is limited (as a consequence of such as rapid industrialization and urbanization), natural disaster impacts and declining agricultural productivity could compound the risk of food insecurity and agricultural growth in Vietnam. Secondly, Vietnam is considered as one of the most affected countries in the world by climate change (World Bank, 2009). Thirdly, our data come from the Vietnamese Access to Resources Household Survey (VARHS) for 2008 and 2010 and include uniquely detailed information on farm-level rice production, and the various types of natural disaster, their time of occurrences, and their levels of severity on rice plots and these allow for the analysis of farm-level rice production and natural disaster.

Findings from the study can provide useful information for policy makers on the adverse effects of natural disaster on rice production and coping strategies in developing countries. If natural disaster results in the depletion of rice productivity, the government should have strong and effective policies and programs to reduce the adverse effects of natural disaster. Moreover, effective coping strategies to deal with the negative effects from natural disaster should be promoted and tailored more in a national framework to fight against natural disaster.

The study is expected to contribute to the literature of environmental economics and development economics in some ways. Firstly, it provides empirical findings on the impacts of natural disaster and of coping strategies on rice production that is still silent in most empirical literature so far. Secondly, it distinguishes between current and inter-temporal effects and occurrence and severity effects as well.

\section{Materials and methodology}

\section{Data}

The data are taken from VARHS for 2008 and 2010, which are results of a joint project conducted by the Central Institute for Economic Management (CIEM) of the Ministry of Planning and Investment (MPI), the Centre for Agricultural Policy Consulting (the Institute of Policy and Strategy for Agriculture and Rural Development - CAP-IPSARD), which is belonged to the Ministry of Agriculture and Rural Development (MARD), the Institute of Labor Science and Social Affairs (ILSSA) (Ministry of Labour, Invalids and Social Affairs - MoLISA), and the Development Economics Research Group (DERG) of the University of Copenhagen, together with Danida.

The VARHS was carried out in rural areas of 12 provinces of Vietnam in the summer of each year. The survey was conducted during the same three-month period each year to ensure consistency and facilitating reasonable comparisons across time. The VARHS explores issues surrounding Vietnamese rural households' access to resources and the constraints that these households face in managing their livelihoods. Along with detailed information on farm-level rice production, the survey includes sections on natural disasters. After refining the dataset between 2008 and 2010, we obtain a balanced two-wave panel of 1,961 households involved in rice production.

Information on natural disaster are gathered by asking farms to name specific natural disasters from a list of natural disasters on each plot cultivated. The list of natural disasters includes flood, drought, typhoon, land slide. The questionnaire also includes an estimation of the loss that farm suffered from the natural disasters with respect to values of output lost on the plot in terms of Vietnamese Dong (VND). Table 1 provides a more detailed breakdown of natural disasters and their sub-categories among rice producers.

We find that that 4.03 per cent of farms faced a natural disaster on their rice plots in 2008 and 5.2 percent in 2010, in general. At a disaggregated level, in 2010 we find that 0.46 per cent of farms suffered a flood (down from 2.35 per cent in 2008) while 4.28 per cent suffered a drought (up from 1.22 per cent in 2008). In 2010, typhoon also increase to 0.31 per cent from 0.15 per cent in 2008 .

Farms can cope with natural disasters in a variety of ways. Table 2 provides a brief description of each type of coping. While over time farms tend to be dependent more on selling land, livestock, assets, getting assistance from relatives or friends, government, NGO, borrowing from banks or relatives and using savings between 2008 and 2010, the less proportion of farms choose to reduce consumption in 2010 compared with 2008.

Table 3 presents the crops of farmers in the 2008-2010 VARHS survey. Information collected on annual and perennial crop plots of 2008 indicates that rice is the highest frequency 


\begin{tabular}{lrcrrrr}
\hline \multirow{2}{*}{ Disaster type } & \multicolumn{2}{c}{$\mathbf{2 0 0 8}$} & \multicolumn{2}{c}{$\mathbf{2 0 1 0}$} & \multicolumn{2}{c}{ Total } \\
\cline { 2 - 7 } & Obs. & Percent (\%) & Obs. & Percent (\%) & Obs. & Percent (\%) \\
\hline No disaster & 1,882 & 95.97 & 1,859 & 94.8 & 3,741 & 95.39 \\
Flood & 46 & 2.35 & 9 & 0.46 & 55 & 1.40 \\
Drought & 24 & 1.22 & 84 & 4.28 & 108 & 2.75 \\
Typhoon & 3 & 0.15 & 6 & 0.31 & 9 & 0.23 \\
Land slide & 6 & 0.31 & 3 & 0.15 & 9 & 0.23 \\
\hline Total & $\mathbf{1 , 9 6 1}$ & $\mathbf{1 0 0}$ & $\mathbf{1 , 9 6 1}$ & $\mathbf{1 0 0}$ & $\mathbf{3 , 9 2 2}$ & $\mathbf{1 0 0}$ \\
\hline
\end{tabular}

Source: Author' calculation from VARHS 2008-2010

Table 1: Disasters by types, 2008-2010.

\begin{tabular}{lrrrrrr}
\hline \multirow{2}{*}{ Coping strategies } & \multicolumn{2}{c}{$\mathbf{2 0 0 8}$} & \multicolumn{2}{c}{ 2010 } & \multicolumn{2}{c}{ Total } \\
\cline { 2 - 6 } Doing nothing & Obs. & Percent (\%) & Obs. & Percent (\%) & Obs. & Percent (\%) \\
Reduce consumption & 1,237 & 63.08 & 1,202 & 61.3 & 2,439 & 62.19 \\
Sold land, livestock, assets & 558 & 28.45 & 416 & 21.21 & 974 & 24.83 \\
Got assistance from relatives or friends & 27 & 1.38 & 48 & 2.45 & 75 & 1.91 \\
Got assistance from Government & 19 & 1.12 & 29 & 1.48 & 51 & 1.30 \\
Got assistance from NGO & 22 & 0.97 & 37 & 1.89 & 56 & 1.43 \\
Borrowed money from bank, others & 51 & 2.60 & 64 & 3.26 & 115 & 0.13 \\
Use savings & 45 & 2.29 & 162 & 8.26 & 207 & 5.93 \\
\hline Total & $\mathbf{1 , 9 6 1}$ & $\mathbf{1 0 0}$ & $\mathbf{1 , 9 6 1}$ & $\mathbf{1 0 0}$ & $\mathbf{3 , 9 2 2}$ & $\mathbf{1 0 0}$ \\
\hline
\end{tabular}

Source: Author' calculation from VARHS 2008-2010

Table 2: Coping strategies by types, 2008-2010.

\begin{tabular}{|c|c|c|c|c|c|c|c|c|}
\hline \multirow[b]{2}{*}{ Crop } & \multicolumn{4}{|c|}{2008} & \multicolumn{4}{|c|}{2010} \\
\hline & Obs. & $\begin{array}{c}\text { Percent } \\
(\%)\end{array}$ & $\begin{array}{c}\text { Mean } \\
\text { (thous. VND) }\end{array}$ & $\begin{array}{c}\text { Std. dev. } \\
\text { (thous. VND) }\end{array}$ & Obs. & $\begin{array}{l}\text { Percent } \\
(\%)\end{array}$ & $\begin{array}{c}\text { Mean } \\
\text { (thous. VND) }\end{array}$ & $\begin{array}{c}\text { Std. dev. } \\
\text { (thous. VND) }\end{array}$ \\
\hline Rice & 2,470 & 43.97 & 12739 & 29446 & 2,386 & 30.62 & 13472 & 32082 \\
\hline Maize & 1,286 & 22.89 & 4213 & 7551 & 1,243 & 15.95 & 5004 & 8560 \\
\hline Potato (non-sweet) & 12 & 0.21 & 1306 & 1264 & 27 & 0.35 & 1715 & 1793 \\
\hline Sweet potato & 104 & 1.85 & 840 & 1394 & 81 & 1.04 & 2440 & 4614 \\
\hline Cassava & 652 & 11.61 & 3464 & 5273 & 639 & 8.20 & 3166 & 7339 \\
\hline Peanuts & 226 & 4.02 & 4077 & 10039 & 212 & 2.72 & 4006 & 13178 \\
\hline Vegetables & na & na & na & na & 664 & 8.52 & 2551 & 6201 \\
\hline Other annual crops & na & na & na & na & 476 & 6.11 & 6299 & 22180 \\
\hline Fruits & 44 & 0.78 & 3333 & 4332 & 949 & 12.18 & 1662 & 4304 \\
\hline Coffee & 394 & 7.01 & 52956 & 63287 & 435 & 5.58 & 51504 & 64727 \\
\hline Tea & 101 & 1.80 & 4982 & 7089 & 111 & 1.42 & 5184 & 7621 \\
\hline Cocoa & na & na & na & na & 16 & 0.21 & 8250 & 9546 \\
\hline Cashew nuts & 154 & 2.74 & 4511 & 7067 & 182 & 2.34 & 10752 & 15606 \\
\hline Sugar cane & 42 & 0.75 & 15302 & 24191 & 51 & 0.65 & 19567 & 39732 \\
\hline Pepper & 116 & 2.07 & 30165 & 55930 & 88 & 1.13 & 35701 & 50698 \\
\hline Rubber & 16 & 0.28 & 40289 & 57807 & 41 & 0.53 & 75225 & 62585 \\
\hline $\begin{array}{l}\text { Medicinal trees/ } \\
\text { plants }\end{array}$ & na & na & na & na & 67 & 0.86 & 8844 & 11206 \\
\hline Other perennial crops & na & na & na & na & 124 & 1.59 & 8362 & 14031 \\
\hline Forestry & na & na & na & na & 1 & 0.01 & 500 & na \\
\hline Total & 5,617 & & & & 7,793 & & & \\
\hline
\end{tabular}

Note: na: no information

Source: Author' calculation from VARHS 2008-2010

Table 3: Cultivation activities by types and crop values (thousand VND), 2008-2010. 
crop, followed by maize, cassava and coffee. Data for 2010 show that rice is still the most frequently planted crop, followed by maize, fruit trees, vegetables and cassava. There is a big difference in fruit trees between the two years of the survey, possibly because farmers responded to the food price decline in 2008.

Table 3 also presents the value of crop production of farmers in the two years 2008-2010. In 2008, among the short-term crops, rice had the highest average farmer production value, about 13 million VND per year, followed by maize, and peanut. In 2010, the average production value of rice farmers is over 13 million VND per year, followed by maize and peanut. In general, in the two years 2008-2010, there was no significant change in the value of production and the hierarchy of short-term crops.

Review of related literature and empirical approach

Most of related empirical works so far are on the impacts of natural disasters on agriculture in general, for example: Loayza, et al. (2009), Sivakumar (2005), and Long (1978). Loayza, et al. (2009) find that droughts and storms have negative impacts on agriculture while floods have a positive effect. Sivakumar (2005) argues that the predominant impacts of natural disasters on agriculture are negative. Long (1978) indicates that the negative effects are a powerful partial explanation of the lack of agricultural selfsufficiency in a large number of low income countries.

An exception is Israel and Briones (2012), who use the Agricultural Multi-market Model for Policy Evaluation (AMPLE) to examine the impacts of natural disasters such as typhoons, floods and droughts on agriculture at the provincial level in the Philippines. They find that typhoons have a significant negative impact on paddy rice production at the provincial level.

Our empirical investigation focuses on: the extent to which natural disaster affects farm-level rice productivity and the extent to which farms manage to cope with adverse effects of natural disaster within the framework of traditional Cobb-Douglas production function as illustrated by Te'o (1997). We follow two stages of empirical investigations to explore these issues. First, we analyses the impacts of natural disaster on farm-level rice productivity. The relationship between natural disaster and the depletion of the farm productivity can be identified using a panel fixed-effects approach under certain assumptions. We exploit the panel dimension to our data by using a fixed effects model that controls for time invariant farm heterogeneity. Time varying farm characteristics are also included as control variables. The key explanatory variables of interest are the different types of natural disaster and the severity and persistence of these natural disasters. Our data facilitate the disaggregation of overall natural disaster into specific natural disasters, which are all exogenous to the model. Using a fixed effects estimation procedure will eliminate any time invariant unobserved heterogeneity while the inclusion of control variables for inputs to capture any remaining time varying heterogeneity. The full farm level fixed effects model we estimate is given by:

$$
\begin{aligned}
& Y_{i t}=\left(\alpha_{1} L A B_{i t}+\alpha_{2} L A N D_{i t}+\alpha_{3} C A P_{i t}+\alpha_{4} M A T E_{i t}\right) \\
& +\beta \sum_{1}^{3} N A T_{i t}^{j}++\chi \sum_{1}^{3} \operatorname{LOSS}_{i t}^{j}+\delta \sum_{1}^{3} N A T L O S S_{i t}^{j} \\
& +\delta_{4} N A T L O S S 21_{i t}++\delta_{5} N A T L O S S 31_{i t} \\
& +\delta_{6} N A T L O S S 32_{i t}+\tau_{\mathrm{i}}+\mathrm{u}_{\mathrm{i}}+\varepsilon_{i t}
\end{aligned}
$$

Where:

$Y_{i t}$ is rice productivity (measured by tons per hectare and in natural logarithm form as used in, for example, Yu et al. (2010));

$L A B_{i t}, L A N D_{i t}, C A P_{i t}, M A T E_{i t}$ represents a vector of farm production inputs (such as labor (total of working days), land (arable land for rice cultivation), capital (annual capital investment), and intermediate costs for rice cultivation. These variables are in natural logarithm form. Economic theory said that higher rice yields are characterized by higher input usage (labor, land, capital, and intermediates such as fertilizer) during the production process;

$N A T^{j}{ }_{i t}(\mathrm{j}=1,2,3)$ are zero-one dummy variables indicating natural disaster occurred in survey year $(t)$, one year before $(t-1)$ and two years before $(t-2)$, respectively. If the current natural disaster resulted in a loss in yield of rice, we would expect the coefficient on this term to be negative and statistically significant (the current occurrence effect); and if the past natural disaster resulted in a loss in yield of rice, we would expect the coefficient on these terms to be negative and statistically significant (the inter-temporal occurrence effect);

$\operatorname{LOSS}_{i t}(j=1,2,3)$ are variables indicating total loss from natural disaster on rice plots occurred in survey year $(t)$, one year before $(t-1)$ and two years before $(t-2)$, respectively. These variables are in natural logarithm form; 
NATLOSS $_{i t}^{j}(j=1,2,3) \quad$ are variables indicating interactions between natural disaster and total loss (in natural logarithm form) from natural disaster on rice plots occurred in survey year $(t)$, one year before $(t-1)$ and two years before $(t-2)$, respectively. If natural disasters are severe, resulted in a loss in yield of rice, we would expect the coefficient on these above interaction terms to be negative and statistically significant (the current severity effects, respectively);

NATLOSS $21_{i t}$, is interaction between natural disaster at last year $(t-1)$ and total loss (in natural logarithm form) from natural disaster on rice plots occurred at current year $(t)$; and NATLOSS $31_{i t}$ and NATLOSS32 are interactions between natural disaster occurred two years ago $(t-2)$ and total loss (in natural logarithm form) from natural disaster on rice plots occurred at current year $(t)$ and last year $(t-1)$, respectively. If natural disasters are severe, resulted in a loss in yield of rice, we would expect the coefficient on these above interaction terms to be negative and statistically significant (the inter-temporal severity effects);

$\tau_{t}$ represents time dummies, $u_{i}$ is a farm specific fixed effect and $\varepsilon_{i t}$ is the farm random error term. We assume that regional differences which control for rice productivity variations and across regions are subsumed within the farm fixed effect while the time dummies control for changes in technology over time.

We explore model (A) into four sub-models: (a) Model 1a with natural disaster, (b) Model 2a with natural disaster, loss, and interactions between natural disaster and loss, (c) Model 1b with specific natural disasters such as flood, drought, typhoon and land slide, (d) Model 2b with specific natural disasters such as flood, drought, typhoon and land slide, their respective losses, and their interactions between specific natural disasters and their respective losses.

At the second stage, our analysis is further extended to consider the extent to which coping strategies may serve to lessen the depletion of farm productivity. We consider seven types of coping strategies, namely: (1) 'reduced consumption', (2) 'sold land, livestock, assets', (3) 'got assistance from relatives or friends', (4) 'got assistance from Government', (5) 'got assistance from NGO', (6) 'borrowed money from bank, others', and (7) 'used savings'. A specified model is as follows:

$$
\begin{aligned}
& Y_{i t}=\left(\alpha_{1} L A B_{i t}+\alpha_{2} L A N D_{i t}+\alpha_{3} C A P_{i t}+\alpha_{4} M A T E_{i t}\right) \\
& +\beta \sum_{1}^{3} N A T^{j}++\chi \sum_{1}^{3} \operatorname{LOSS}_{i t}^{j}+\delta \sum_{1}^{3} N A T L O S S_{i t}^{j} \\
& +\delta_{4} N A T L O S S 21_{i t}++\delta_{5} N A T L O S S 31_{i t} \\
& +\delta_{6} N A T L O S S 32_{i t}+\phi_{1} \sum_{1}^{7} C O P_{i t}^{j}+\phi_{2} \sum_{1}^{7} \operatorname{COPLG1} 1_{i t}^{j} \\
& +\phi 3 \sum_{1}^{7} \operatorname{COPLG} 2_{i t}^{j}+\varphi_{1} \sum_{1}^{7} \operatorname{COPNAT_{it}^{j}}+\varphi_{2} \sum_{1}^{7} \operatorname{COPNATLG1_{it}^{j}}
\end{aligned}
$$

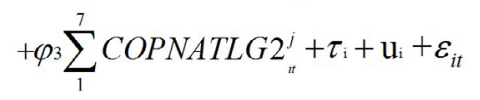

Where:

$C O P{ }_{i t}^{j}, C O P L G 1^{j}{ }_{i t}$, and COPLG $2^{j}{ }_{i t}(j=1,2,3,4,5,6,7)$ are zero-one dummy variables indicating seven specific coping strategies conducted in survey $(t)$, one year before $(t-1)$ and two years before $(t-2)$, respectively. If copping strategies help to lessen the depletion of rice productivity in the event of a natural disaster, we would expect the coefficient on these interaction terms to be positive and statistically significant (the positive current coping-occurrence effects); if not, the coefficients can be negative and statistically significant (the negative current coping-occurrence effects).

COPNAT ${ }_{i t}$, COPNATLG $1^{j}{ }_{i t}$, and COPNATLG $2^{j}{ }_{i t}$ $(j=1,2,3,4,5,6,7)$ are interactions between natural disaster and seven specific coping strategies in survey $(t)$, one year before $(t-1)$ and two years before $(t-2)$, respectively. If copping strategies help to lessen the depletion of rice productivity in the event of a natural disaster, we would expect the coefficient on these interaction terms to be positive and statistically significant (the positive inter-temporal coping-occurrence effects); if not, the coefficients can be negative and statistically significant (the negative inter-temporal copingoccurrence effects).

We explore model (B) into four sub-models: (a) Model 3a with natural disaster, coping strategies, and interactions between natural disaster and coping strategies, (b) Model 4a with natural disaster, loss, their interactions, coping strategies, and interactions between natural disaster and coping strategies, (c) Model 3b with specific natural disasters, coping strategies, and interactions between specific natural disasters and coping strategies, (d) Model $4 \mathrm{~b}$ with specific disasters, loss, their interactions, coping strategies, and interactions between specific disasters and coping strategies.

Outliers are always hidden in the questionnaire survey. In this study, we suspected outlier observations on the variables of rice area, rice yield, and rice yield of farmers. With these three variables 
we cannot apply the conventional method to identify and eliminate outlier observations, so we use bacon command in Stata to identify multivariate outliers (Weber, 2010). After removing outliers, we obtain a two-wave panel dataset of 3922 observations.

During the regression analysis, multicollinearity and heteroskedasticity are examined and the results show that there is no multicollinearity and no evidence of unequal variance. In addition, we present the regression results after the procedure for eliminating natural disasters related variables that do not pass the statistical significance test at the common levels.

\section{Results and discussion}

The summary statistics presented in Materials and methods help to motivate the central research questions of this paper concerning the impact of natural disaster on farm-level rice production. As discussed in Section 3, there are two parts to our empirical investigation of these issues. First, we estimate a fixed effects model of the impact of natural disaster on farms' rice productivity. Second, we focus on the impacts of coping strategies to farms' rice productivity under natural disaster to gain an understanding of the extent to which coping strategies are effective.

\section{Statistic description}

Table 4 presents descriptive statistics for the years 2008 and 2010 on the annual sample. There is no significant change in the average annual production of rice between 2008 and 2010, at about 1.8 tones. However, there is a significant change in paddy yield between 2008 (4.22 tons per ha) and 2010 (4.48 tons per ha). Labor size has not changed between two years (approximately 3 labors in 2008 and 2010). However, the number of working days devoted to rice cultivation has changed much: 125 days in 2008 and 101 days in 2010. Rice cultivation area remains unchanged in 2008 and 2010, at about 0.45 hectares. There is an increase in investment between 2008 and 2010, about 928 thousand VND in 2008 to about 1.3 million VND in 2010. The cost of production also increased about 2.5 million VND in 2008 to nearly 6.0 million VND in 2010 .

Table 5 also shows that that from less than 1 per cent to 18 per cent of rice cultivating firms suffered natural disaster between 2007 and 2010 . At a disaggregated level, in 2007 we find that

\begin{tabular}{|c|c|c|c|c|c|c|c|c|}
\hline \multirow[t]{2}{*}{ Variable } & Mean & Std. Dev. & Min. & Max. & Mean & Std. Dev. & Min. & Max. \\
\hline & \multicolumn{4}{|c|}{$2008(N=1969)$} & \multicolumn{4}{|c|}{$2010(N=1969)$} \\
\hline Rice output (tons) & 1.80 & 1.36 & 0.03 & 10.80 & 1.73 & 1.31 & 0.05 & 10.50 \\
\hline Rice productivity (Tons/ha) & 4.48 & 1.50 & 0.20 & 10.00 & 4.22 & 1.44 & 0.25 & 11.43 \\
\hline Number of labor & 3.08 & 1.46 & 1.00 & 10.00 & 3.17 & 1.48 & 1.00 & 9.00 \\
\hline Number of working days for rice (days) & 124.59 & 87.85 & 2.00 & 660.00 & 101.25 & 64.51 & 3.00 & 520.00 \\
\hline Arable land for rice (hectare) & 0.45 & 0.36 & 0.01 & 2.9 & 0.46 & 0.39 & 0.01 & 3.80 \\
\hline Total investment (thousand VND) & 928.54 & 3674 & 0.00 & 70035 & 1287.41 & 4240.63 & 0.00 & 45100 \\
\hline Input costs (thousand VND) & 2518 & 2722 & 0.00 & 35500 & 5947.27 & 9257 & 0.00 & 128230 \\
\hline
\end{tabular}

Source: Authors' calculation from VARHS 2008-2010

Table 4: Statistic summary on factor variables, 2008-2010.

\begin{tabular}{|c|c|c|c|c|c|c|c|c|c|}
\hline \multirow{2}{*}{ Variable } & \multicolumn{2}{|c|}{2008} & \multicolumn{2}{|c|}{2010} & \multirow{2}{*}{ Variable } & \multicolumn{2}{|c|}{2008} & \multicolumn{2}{|c|}{2010} \\
\hline & Mean & Std. Dev. & Mean & Std. Dev. & & Mean & Std. Dev. & Mean & Std. Dev. \\
\hline Natural disaster at year $\mathrm{t}(\mathrm{Yes}=1)$ & 0.0331 & 0.1791 & 0.0495 & 0.2169 & $\begin{array}{l}\text { Got assistance from relatives or friends } \\
\text { at year } \mathrm{t}(\mathrm{Yes}=1)\end{array}$ & 0.0112 & 0.1053 & 0.0214 & 0.1448 \\
\hline Natural disaster at year $(\mathrm{t}-1)(\mathrm{Yes}=1)$ & 0.1260 & 0.3319 & 0.1836 & 0.3872 & $\begin{array}{l}\text { Got assistance from Government } \\
\text { at year } \mathrm{t}(\mathrm{Yes}=1)\end{array}$ & 0.0102 & 0.1005 & 0.0224 & 0.1481 \\
\hline Natural disaster at year $(\mathrm{t}-2)($ Yes $=1)$ & 0.0041 & 0.0638 & 0.0617 & 0.2407 & $\begin{array}{l}\text { Got assistance from NGOs at year } t \\
(\text { Yes }=1)\end{array}$ & 0.0010 & 0.0319 & 0.0015 & 0.0391 \\
\hline Flood at year $\mathrm{t}($ Yes $=1)$ & 0.0235 & 0.1514 & 0.0066 & 0.0812 & $\begin{array}{l}\text { Borrowed money from bank, others } \\
\text { at year } \mathrm{t}(\text { Yes }=1)\end{array}$ & 0.0265 & 0.1607 & 0.0403 & 0.1967 \\
\hline Flood at year $(t-1)($ Yes $=1)$ & 0.0796 & 0.2707 & 0.0637 & 0.2444 & Used savings at year $\mathrm{t}(\mathrm{Yes}=1)$ & 0.0229 & 0.1498 & 0.0826 & 0.2754 \\
\hline Flood at year $(t-2)(Y e s=1)$ & 0.0036 & 0.0597 & 0.0566 & 0.2311 & $\begin{array}{l}\text { Reduced consumption at year }(\mathrm{t}-1) \\
(\text { Yes }=1)\end{array}$ & 0.3177 & 0.4657 & 0.2743 & 0.4463 \\
\hline Drought at year $\mathrm{t}\left(\mathrm{Yes}^{\prime}=1\right)$ & 0.0122 & 0.1100 & 0.0444 & 0.2060 & $\begin{array}{l}\text { Sold land, livestock, assets at year }(\mathrm{t}-1) \\
(\text { Yes }=1)\end{array}$ & 0.0127 & 0.1122 & 0.0454 & 0.2082 \\
\hline
\end{tabular}

Source: Authors' calculation from VARHS 2008-2010

Table 5: Statistic summary on natural disaster and coping strategies, 2008 -2010 (to be continued). 
Effects of Natural Disaster on Rice Production at Farm Level: New Evidence from Vietnam

\begin{tabular}{|c|c|c|c|c|c|c|c|c|c|}
\hline \multirow{2}{*}{ Variable } & \multicolumn{2}{|c|}{2008} & \multicolumn{2}{|c|}{2010} & \multirow{2}{*}{ Variable } & \multicolumn{2}{|c|}{2008} & \multicolumn{2}{|c|}{2010} \\
\hline & Mean & Std. Dev. & Mean & Std. Dev. & & Mean & Std. Dev. & Mean & Std. Dev. \\
\hline Drought at year $(\mathrm{t}-1)(\mathrm{Yes}=1)$ & 0.0352 & 0.1843 & 0.0938 & 0.2917 & $\begin{array}{l}\text { Got assistance from relatives or friends } \\
\text { at year }(\mathrm{t}-1)(\mathrm{Yes}=1)\end{array}$ & 0.0122 & 0.1100 & 0.0224 & 0.1481 \\
\hline Drought at year $(\mathrm{t}-2)(\mathrm{Yes}=1)$ & 0.0005 & 0.0226 & 0.0056 & 0.0747 & $\begin{array}{l}\text { Got assistance from Government at year } \\
(\mathrm{t}-1)\left(\mathrm{Yes}^{\prime}=1\right)\end{array}$ & 0.0102 & 0.1005 & 0.0245 & 0.1546 \\
\hline Typhoon at year t $($ Yes=1) & 0.0015 & 0.0391 & 0.0031 & 0.0552 & $\begin{array}{l}\text { Got assistance from NGOs at year }(\mathrm{t}-1) \\
(\mathrm{Yes}=1)\end{array}$ & 0.0020 & 0.0451 & 0.0031 & 0.0552 \\
\hline Typhoon at year $(\mathrm{t}-1)(\mathrm{Yes}=1)$ & 0.0087 & 0.0927 & 0.0311 & 0.1737 & $\begin{array}{l}\text { Borrowed money from bank, others } \\
\text { at year }(t-1)(\text { Yes }=1)\end{array}$ & 0.0286 & 0.1666 & 0.0428 & 0.2025 \\
\hline Typhoon at year $(t-2)(Y e s=1)$ & 0 & 0 & 0.0010 & 0.0319 & Used savings at year $(\mathrm{t}-1)(\mathrm{Yes}=1)$ & 0.0316 & 0.1750 & 0.0903 & 0.2866 \\
\hline Landslides at year $\mathrm{t}(\mathrm{Yes}=1)$ & 0.0031 & 0.0552 & 0.0015 & 0.0391 & $\begin{array}{l}\text { Reduced consumption at year }(\mathrm{t}-2) \\
(\mathrm{Yes}=1)\end{array}$ & 0.3095 & 0.4624 & 0.2458 & 0.4307 \\
\hline Landslides at year $(\mathrm{t}-1)(\mathrm{Yes}=1)$ & 0.0102 & 0.1005 & 0.0143 & 0.1187 & $\begin{array}{l}\text { Sold land, livestock, assets at year }(\mathrm{t}-2) \\
(\text { Yes }=1)\end{array}$ & 0.0122 & 0.1100 & 0.0454 & 0.2082 \\
\hline Landslides at year $(\mathrm{t}-2)(\mathrm{Yes}=1)$ & 0 & 0 & 0.0010 & 0.0319 & $\begin{array}{l}\text { Got assistance from relatives or friends } \\
\text { at year }(t-2)(Y e s=1)\end{array}$ & 0.0112 & 0.1053 & 0.0219 & 0.1465 \\
\hline $\begin{array}{l}\text { Natural disaster loss at year t } \\
\text { (thousand VND) }\end{array}$ & 159 & 680 & 98 & 550 & $\begin{array}{l}\text { Got assistance from Government at year } \\
(\mathrm{t}-2)(\mathrm{Yes}=1)\end{array}$ & 0.0066 & 0.0812 & 0.0250 & 0.1561 \\
\hline $\begin{array}{l}\text { Natural disaster loss at year }(\mathrm{t}-1) \\
\text { (thousand VND) }\end{array}$ & 336 & 1253 & 304 & 1438 & $\begin{array}{l}\text { Got assistance from NGOs at year }(\mathrm{t}-2) \\
(\mathrm{Yes}=1)\end{array}$ & 0.0010 & 0.0319 & 0.0015 & 0.0391 \\
\hline $\begin{array}{l}\text { Natural disaster loss at year }(\mathrm{t}-2) \\
\text { (thousand VND) }\end{array}$ & 16 & 205 & 105 & 880 & $\begin{array}{l}\text { Borrowed money from bank, others } \\
\text { at year }(t-2)(\text { Yes }=1)\end{array}$ & 0.0255 & 0.1577 & 0.0398 & 0.1955 \\
\hline Reduced consumption at year $\mathrm{t}(\mathrm{Yes}=1)$ & 0.3151 & 0.4647 & 0.2407 & 0.4276 & Used savings at year $(t-2)($ Yes $=1)$ & 0.0209 & 0.1431 & 0.0852 & 0.2792 \\
\hline $\begin{array}{l}\text { Sold land, livestock, assets at year } t \\
(\text { Yes }=1)\end{array}$ & 0.0143 & 0.1187 & 0.0444 & 0.2060 & & & & & \\
\hline
\end{tabular}

Source: Authors' calculation from VARHS 2008-2010

Table 5: Statistic summary on natural disaster and coping strategies, 2008 -2010 (continuation).

less than 1 per cent of farms suffered one form of natural disasters such a flood, drought, typhoon, and landslides, while in 2009-2010, flood occurred at 5-6 per cent, drought sometimes at 9 per cent, typhoon at 3 per cent, and landslides at 1 per cent.

The losses as a result of natural disaster varies considerably over time. As revealed in Table 7, the size of losses increases from 16 thousand VND in 2007 to 304 thousand VND in 2009.

With respect to coping strategies, most farms choose to reduce consumption and the percentage is increasing over time, from 31 per cent in 2007 to 43 per cent in 2010 . Coping by selling productive means is also increased over time, from around 1 percent in 2007 to about 21 per cent in 2010 . The proportion farms with assistance from relatives and from Vietnamese government increased between 2007 and 2010 from 1 per cent to 14 per cent of farms. As an important source of finance, farms choosing to borrow from bank increased between 2007 and 2010 from 3 per cent to 20 per cent of farms. We also find that the proportion of farms using savings increased between 2007 and 2010 from 2 per cent to 28 per cent of farms.

\section{Natural disaster effects on rice productivity}

The results of the fixed effects model of the effects of natural disaster on farm-level rice productivity are presented in Table 6. First, we determine whether farms suffering any type of natural disasters experience a statistically significant reduction in rice productivity (the current and intertemporal occurrence effects). Second, we further investigate to which extend the level of severity by natural disaster affect farm-level rice productivity by taking into account the loss from natural disaster and by interacting natural disaster incidence and the loss from natural disaster (the current and inter-temporal severity effects). Third, we disaggregate the natural disaster measure into its specific forms such as flood, drought, typhoon, and landslides to explore how each specific category of natural disasters influences rice productivity over time (the current and intertemporal occurrence effects). Four, we further examine the level of severity by specific natural disasters affecting farm-level rice productivity by taking into account the loss from specific natural disasters and by interacting specific natural disaster incidence and the loss from respectively specific natural disasters (the current and inter-temporal severity effects). In all steps, controls for traditional determinants of rice productivity such as labor, land, capital investment, and intermediate costs and other factors such as recovery from prior shocks (to control for persistence) and time dummies (to control for technology change over time) are included. Table 6 shows, in the second last row of it, that the fixed effects model is preferred than the OLS model. In addition, Hausman test in the last row of the table indicating that the random effect 
estimator is consistent (due to non-zero covariance between residuals and explanatory variables) is rejected. Therefore, we have to rely upon the fixed effect estimator.

Table 6 presents two main parts of estimation results. The first is related to factor variables, and the second all about natural disasters' effects. Although our main concerns are the second, we say somethings about the factor variables. Since production and inputs are measured in their logarithmic forms and are continuous, all the estimated parameters are the elasticities of these inputs. Yield elasticities with respect to household labor is about 0.09 , highlighting the important role of labor in four models. An additional 1 percent working day use (proxied by working days) could increase the yield by 0.09 percent. Intermediates also have a sizable effect on rice yield, and an additional 1 percent intermediates use (proxied by intermediates costs) could increase the yield by 0.05 percent in four models. Annual capital investment is not significant in four models. Land has significantly negative effects on yield in four models. A possible explanation is the arable land size is small (on average, 0.45 ha in 2008 and 0.39 ha in 2010 in our sample and see Markussen (2015) for more description on this issue). Small land size can prevent farmers from mechanization or benefit from economies of scale. Another explanation is the fragmentation of land that also constraints the effectiveness of land use (see, for example, Markussen (2015)).

Regarding to the effect of natural disasters, Model la in Table 6 reveals that natural disaster within the last two years have a negative effect on rice productivity (the negative inter-temporal occurrence effect), which proves to be consistent with past studies (Israel and Briones, 2012; Sivakumar, 2005), while natural disaster at the survey year has no significant effect). Average rice yields among farms with natural disaster in last year are considerably lower than those with no natural disaster in the current year by 4.9 percent. In addition, average rice yields

\begin{tabular}{|c|c|c|c|c|}
\hline Dependent variable: rice productivity (tons per hectare, $\log$ ) & Model 1a & Model 2a & Model 1b & Model 2b \\
\hline \multicolumn{5}{|l|}{ Factor variables } \\
\hline Total of working days (days, log) & $0.0847 * * *(0.0129)$ & $0.0866^{* * *}(0.0128)$ & $0.0853^{* * *}(0.0128)$ & $0.0858^{* * *}(0.0260)$ \\
\hline Arable land for rice cultivation (hectare, log) & $-0.313^{* * *}(0.0199)$ & $-0.314 * * *(0.0198)$ & $-0.312^{* * *}(0.0199)$ & $-0.302 * * *(0.0374)$ \\
\hline Annual capital investment (thousand VND, log) & $0.00189(0.00265)$ & $0.00213(0.00265)$ & $0.00164(0.00265)$ & $0.00255(0.00515)$ \\
\hline Intermediate costs for rice cultivation (thousand VND, log) & $0.0558 * * *(0.00827)$ & $0.0573 * * *(0.00823)$ & $0.0533 * * *(0.00822)$ & $0.0504 * * *(0.0148)$ \\
\hline \multicolumn{5}{|l|}{ Natural disasters related variables } \\
\hline Loss by disaster at year $(\mathrm{t}-1)$ (thousand VND, $\log$ ) & & $-0.00694 * * *(0.00267)$ & & \\
\hline $\begin{array}{l}\text { Disaster at year }(\mathrm{t}-1)(\mathrm{Yes}=1) \text { "Loss by disaster at year }(\mathrm{t}) \\
\text { (thousand VND, log) }\end{array}$ & & $-0.0237 * * *(0.00755)$ & & \\
\hline $\begin{array}{l}\text { Disaster at year }(\mathrm{t}-2)(\mathrm{Yes}=1) \text { "Loss by disaster at year }(\mathrm{t}-1) \\
\text { (thousand VND, } \log )\end{array}$ & & $-0.0278^{* *}(0.0116)$ & & \\
\hline Disaster at year $(\mathrm{t})($ Yes $=1)$ & $-0.0419(0.0352)$ & & & \\
\hline Disaster at year $(\mathrm{t}-1)(\mathrm{Yes}=1)$ & $-0.0493 * *(0.0202)$ & & & \\
\hline Disaster at year $(\mathrm{t}-2)(\mathrm{Yes}=1)$ & $-0.0690 *(0.0400)$ & & & \\
\hline Flood at year $(\mathrm{t})($ Yes $=1)$ & & & $-0.105 *(0.0575)$ & \\
\hline Typhoon at year $(\mathrm{t})($ Yes=1) & & & $-0.323 * *(0.147)$ & \\
\hline Drought at year $(\mathrm{t}-1)(\mathrm{Yes}=1)$ & & & & $-0.574 * * *(0.207)$ \\
\hline Loss by drought at year $(\mathrm{t}-1)$ (thousand VND, $\log$ ) & & & & $-0.0964 * * *(0.0318)$ \\
\hline $\begin{array}{l}\text { Landslide at year }(\mathrm{t}-2)(\text { Yes }=1) \text { "Loss by landslide at year }(\mathrm{t}-1) \\
\text { (thousand VND, log) }\end{array}$ & & & & $-0.0869(0.0731)$ \\
\hline Recovery controlled & Yes & Yes & Yes & Yes \\
\hline Constant & $0.266^{* *}(0.106)$ & $0.260 * *(0.105)$ & $0.275^{* * *}(0.106)$ & $0.275^{* * *}(0.206)$ \\
\hline Observations & 3,922 & 3,922 & 3,922 & 2,122 \\
\hline R-squared within model & 0.118 & 0.129 & 0.117 & 0.115 \\
\hline R-squared between model & 0.274 & 0.287 & 0.271 & 0.212 \\
\hline R-squared overal model & 0.224 & 0.237 & 0.221 & 0.203 \\
\hline $\mathrm{F}$ for $\mathrm{u}_{-} \mathrm{i}=0$ & $1.463 * * *$ & $1.459 * * *$ & $1.496 * * *$ & $1.245^{* * *}$ \\
\hline Hausman test $\left(\mathrm{H}_{0}\right.$ : Difference in coefficients not systematic) & $311.02 * * *$ & $285.39^{* * *}$ & $250.31 * * *$ & $46.55^{* * *}$ \\
\hline
\end{tabular}

Note: Model 1a: Natural disaster; Model 2a: Natural disaster, loss, and interactions; Model 1b: Specific natural disaster; Model 2b: Specific natural disasters, loss, and interactions

Standard errors in parentheses; $* * * \mathrm{p}<0.01, * * \mathrm{p}<0.05, * \mathrm{p}<0.1$

Source: Authors' calculation from VARHS 2008-2010 
among farms with natural disaster in two years ago are considerably lower than those with no natural disaster in the current year by 6.9 percent.

Taking the total loss from natural disaster into account, we find that natural disaster with severity in all time swing of consideration (the survey year, last year and two years ago) do have a significantly negative effect on rice productivity in Model 2a (the negative inter-temporal severity effect). Specifically, a 1 percent loss due to natural disaster in the last year could decrease the yield by nearly 0.01 percent. In addition, a 1 percent loss in the current year due to natural disaster in the last year could decrease the yield by nearly 0.02 percent. Moreover, a 1 percent loss in the last year due to natural disaster in two years ago could decrease the yield by nearly 0.03 percent.

Disaggregating the natural disaster into its specific forms (Model 1b) we find that two types of natural disasters such as flood and typhoon at the survey year have a negative effect on rice productivity (the negative current occurrence effect), which appears to be consistent with past studies (Israel and Briones, 2012; Sivakumar, 2005). Average rice yields among farms with flood in the current year are considerably lower than those with no flood in the current year by 10.5 percent. In addition, average rice yields among farms with typhoon in the current year are considerably lower than those with no typhoon in the current year by 32.3 percent.

A further step to take total loss into consideration (Model 2b) by interacting specific natural disasters with their respective losses reveals that both drought and land slide with severity serve to deplete rice productivity over time (the negative inter-temporal severity effect), which appears to be consistent with the study of Israel and Briones (2012) for the Philippines. Average rice yields among farms with drought in the last year are considerably lower than those with no drought in the last year by 57.4 percent. Furthermore, a 1 percent loss in the last year due to drought could decrease the yield by nearly 0.1 percent. Last but not least, a 1 percent loss in the last year due to landslide in two years ago could decrease the yield by nearly 0.09 percent.

\section{Coping strategies and rice productivity}

The results of the fixed effects model of the effects of coping strategies on farm-level rice productivity are presented in Table 7. First, we determine whether coping strategies conducted by farms suffering any type of natural disasters help to reduce the negative effect of natural disaster on rice productivity (the current and inter-temporal coping-occurrence effects). Second, we further investigate whether coping strategies conducted by farms help to reduce the negative effect of natural disaster on rice productivity by ' taking into account the level of severity by natural disaster (measure by the loss from natural disaster) and by interacting natural disaster incidence and the loss from natural disaster (the current and inter-temporal coping-severity effects). Third, we investigate whether coping strategies conducted by farms help to reduce the negative effect of a specific natural disaster on rice productivity by using information on specific natural disaster on rice plots (the current and inter-temporal copingoccurrence effects). Four, we further examine whether coping strategies conducted by farms help to reduce the negative effect of a specific natural disaster on rice productivity by using information on the severity of specific natural disaster (the current and inter-temporal coping-severity effects). In all steps, controls for traditional determinants of rice productivity such as labor, land, capital investment, and intermediate costs and other factors such as recovery from prior shocks (to control for persistence) and time dummies (to control for technology change over time) are included. As a step to determine whether fixed effects model or OLS one is preferred, Table 7 shows, in the second last row of it, that the fixed effects model is preferred than the OLS model. In addition, Hausman test in the last row of the table indicating that the random effect estimator is consistent (due to non-zero covariance between residuals and explanatory variables) is rejected. Therefore, we have to rely upon the fixed effect estimator.

While selling productive means such as land, livestock, assets as a coping strategy has been discussed in, for example, Fafchamps (2009) in general case, and Rosenzweig and Wolpin (1993) for the case of India, Model 3a reveals some mixed results from selling productive means. On the one hand, selling productive means such as land, livestock, assets in the last year can reduce rice productivity at current year (the negative inter-temporal coping-occurrence effect). On the other hand, selling productive means such as land, livestock, assets in the two years ago can increase rice productivity at current year (the positive inter-temporal coping-occurrence effect). This is further confirmed when taking into account the severity of natural disaster in Model 3b (both the positive and negative inter- 


\begin{tabular}{|c|c|c|c|c|}
\hline Dependent variable: rice productivity (tons per hectare, $\log$ ) & Model 3a & Model 4a & Model 3b & Model 4b \\
\hline \multicolumn{5}{|l|}{ Factor variables } \\
\hline Total of working days (days, log) & $0.0819 * * *(0.0129)$ & $0.0843^{* * *}(0.0127)$ & $0.0807^{* * *}(0.0128)$ & $0.0777^{* * *}(0.0262)$ \\
\hline Arable land for rice cultivation (hectare, $\log$ ) & $-0.312 * * *(0.0199)$ & $-0.313 * * *(0.0198)$ & $-0.312 * * *(0.0198)$ & $-0.303 * * *(0.0372)$ \\
\hline Annual capital investment (thousand VND, log) & $0.00160(0.00264)$ & $0.00190(0.00264)$ & $0.00170(0.00263)$ & $0.00277(0.00513)$ \\
\hline Intermediate costs for rice cultivation (thousand VND, $\log$ ) & $0.0577^{* * *}(0.00824)$ & $0.0594 * * *(0.00820)$ & $0.0583 * * *(0.00829)$ & $0.0596^{* * *}(0.0152)$ \\
\hline \multicolumn{5}{|l|}{ Natural disasters related variables } \\
\hline Loss by disaster at year $(\mathrm{t}-1)$ (thousand VND, $\log$ ) & & $-0.00632 * *(0.00266)$ & & \\
\hline $\begin{array}{l}\text { Disaster at year }(\mathrm{t}-1)(\text { Yes }=1) * \text { Loss by disaster at year }(\mathrm{t}) \\
\text { (thousand VND, } \log )\end{array}$ & & $-0.0253 * * *(0.00751)$ & & \\
\hline $\begin{array}{l}\text { Disaster at year }(\mathrm{t}-2)(\mathrm{Yes}=1) * \text { Loss by disaster at year }(\mathrm{t}-1) \\
\text { (thousand VND, } \log )\end{array}$ & & $-0.0269 * *(0.0116)$ & & \\
\hline Disaster at year $(\mathrm{t})(\mathrm{Yes}=1)$ & $-0.0403(0.0350)$ & & & \\
\hline Disaster at year $(\mathrm{t}-1)(\mathrm{Yes}=1)$ & $-0.0371 *(0.0204)$ & & & \\
\hline Disaster at year $(\mathrm{t}-2)(\mathrm{Yes}=1)$ & $-0.0752 *(0.0400)$ & & & \\
\hline Flood at year $(\mathrm{t})($ Yes $=1)$ & & & $-0.110 *(0.0572)$ & \\
\hline Typhoon at year $(\mathrm{t})($ Yes=1) & & & $-0.306 * *(0.147)$ & \\
\hline Drought at year $(\mathrm{t}-1)(\mathrm{Yes}=1)$ & & & & $0.671 * * *(0.211)$ \\
\hline Loss by drought at year $(\mathrm{t}-1)$ (thousand VND, $\log$ ) & & & & $-0.109^{* * *}(0.0321)$ \\
\hline $\begin{array}{l}\text { Landslide at year }(\mathrm{t}-2)(\mathrm{Yes}=1) * \text { Loss by landslide at year }(\mathrm{t}-1) \\
\text { (thousand VND, log) }\end{array}$ & & & & $-0.104(0.0732)$ \\
\hline \multicolumn{5}{|l|}{ Coping measures } \\
\hline Got assistance from NGO at year (t) $(\mathrm{Yes}=1)$ & $-0.284(0.197)$ & $-0.296(0.196)$ & $-0.305(0.197)$ & \\
\hline Sold productive means at year $(\mathrm{t}-1)($ Yes $=1)$ & $-0.705^{* * *}(0.198)$ & $-0.711^{* * *}(0.197)$ & $-0.665^{* * *}(0.197)$ & \\
\hline Sold productive means at year $(\mathrm{t}-2)(\text { Yes }=1)_{-}$ & $0.558 * * *(0.199)$ & $0.556^{* * *}(0.197)$ & $0.511 * * *(0.198)$ & \\
\hline Used savings at year $(\mathrm{t}-2)(\mathrm{Yes}=1)$ & & & $-0.0644 * *(0.0323)$ & $-0.110 * *(0.0467)$ \\
\hline Recovery controlled & Yes & Yes & Yes & Yes \\
\hline Constant & $0.269 * *(0.105)$ & $0.250 * *(0.105)$ & $0.265 * *(0.105)$ & $0.246^{* * *}(0.205)$ \\
\hline Observations & 3,922 & 3,922 & 2,122 & 2,122 \\
\hline R-squared within model & 0.129 & 0.139 & 0.131 & 0.123 \\
\hline R-squared between model & 0.277 & 0.291 & 0.278 & 0.210 \\
\hline R-squared overal model & 0.229 & 0.242 & 0.231 & 0.204 \\
\hline $\mathrm{F}$ for $\mathrm{u}_{-} \mathrm{i}=0$ & $1.477 * * *$ & $1.474 * * *$ & $1.506^{* * *}$ & $1.256^{* * *}$ \\
\hline Hausman test $\left(\mathrm{H}_{0}\right.$ : Difference in coefficients not systematic) & $317.18^{* * *}$ & $292.77^{* * *}$ & $250.05^{* * *}$ & $49.50^{* * *}$ \\
\hline
\end{tabular}

Note: Model 3a: Natural disaster, coping strategies, and interactions; Model 3b: Natural disaster, loss, coping strategies, and interactions; Model 4a: Specific natural disaster, coping strategies, and interactions; Model 4b: Specific natural disasters, loss, their interactions, coping strategies, and interaction

Standard errors in parentheses; $* * * \mathrm{p}<0.01, * * \mathrm{p}<0.05, * \mathrm{p}<0.1$

Source: Authors' calculation from VARHS 2008-2010

Table 7: Effects of coping strategies on rice productivity, 2008-2010.

temporal coping-occurrence effects of selling productive means).

On top of that, disaggregating the natural disaster into its specific forms, both the positive and negative inter-temporal coping-occurrence effects of selling productive means) is confirmed (Model 4b). In addition, the negative inter-temporal copingoccurrence effect from using savings at the point of two years ago is confirmed (Model $3 b$ and $4 b$ ). Findings from theoretical models by Zeldes (1989), Kimball (1990), studies by Deaton (1992) for developing countries, and Udry (1994) in Nigeria suggest that savings (especially for poor rural households) appear to be a pre-emptive response to income shocks rather than a long-term investment decision. Thus, a plausible explanation is using savings in the past may deplete the productivity through a shortage of financial resource at the current time.

We did not find significant coping evidence of borrowing money from bank, assistances from relatives, NGOs, and government.

\section{Conclusion}

Rice production in Vietnam faces severe challenges from natural disaster. In the current paper, we examine the consequences of natural disaster 
on rice production of Vietnamese farms by examining the impacts of natural disaster and coping strategies as well on rice productivity. We exploit the panel dimension to the dataset of rice production with 3,922 households by using a fixed effects model that controls for time invariant farm heterogeneity. Time varying farm characteristics are also included as control variables.

When natural disaster variable in general is used, we find that natural disaster within the last two years have a negative effect on rice productivity (the negative inter-temporal occurrence effect). Taking the total loss from natural disaster into account, we find that natural disaster with severity in all time swing of consideration (the survey year, last year and two years ago) do have a significantly negative effect on rice productivity (the negative inter-temporal severity effect).

Disaggregating the natural disaster into its specific forms, we find that two types of natural disasters such as flood and typhoon at the survey year have a negative effect on rice productivity (the negative current occurrence effect). Taking total loss into consideration, estimation reveals that both drought and land slide with severity serve to deplete rice productivity over time (the negative inter-temporal severity effect).

With regarding to coping strategies, selling productive means such as land, livestock, assets have both the negative inter-temporal copingoccurrence effect and the positive inter-temporal coping-occurrence effect, depending the length of occurrences. With regarding to savings as a source of coping, we find the negative intertemporal coping-occurrence effect. We did not find significant coping evidence of borrowing money from bank, assistance from relatives, NGOs, and government.

Based on its results and findings, the study recommends the following: (i) Since specific natural disasters may have significantly and differently negative impacts on rice production at the farm level, assistance for rice farmers and the agriculture sector as a whole should be made more site and crops-specific; (ii) the findings provide evidence for the importance of financial resources in support for farms in rice production where natural disaster occur. Savings act as important buffers in the face of natural disaster in the short run but in the long run using savings as coping may lead to lower rice productivity given that it results in a shortage of financial resource at the current time, (iii) Coping with selling productive means has both the negative inter-temporal coping-occurrence effect and the negative inter-temporal coping-severity effect, thus it suggests that farms should rely on other available types of coping rather than deplete rice productivity in the long run.

Corresponding authors:

Dr. Quang - Thanh Ngo

Southern Center of Agricultural Policy and Strategy,

Institute of Policy and Strategy for Agriculture and Rural Development,

12 Vo Van Kiet Street, Nguyen Thai Binh Ward, District 1, Ho Chi Minh City, Vietnam

Phone: (84)937105567,E-mail: thanh.ngo@scap.gov.vn

\section{References}

[1] Alderman, H., Hoddinott, J. and Kinsey, B. (2006) "Long term consequences of early childhood malnutrition”, Oxford economic papers, Vol. 58, No. 3, pp. 450-474. E-line ISSN 1464-3812, ISSN 0030-7653. DOI 10.1093/oep/gp1008.

[2] Benson, C. (1997) "The economic impact of natural disasters in Viet Nam", Overseas Development Institute London. ISBN 0850032520.

[3] Blaikie, P., Cannon, T., Davis, I. and Wisner, B. (2014) “At risk: natural hazards, people's vulnerability and disasters", Routledge. ISBN-13 978-0415252164, ISBN-10 0415252164.

[4] Briguglio, L., Cordina, G., Farrugia, N. and Vella, S. (2009) "Economic vulnerability and resilience: concepts and measurements", Oxford development studies, Vol. 37, No. 3, pp. 229-247. DOI 10.1080/13600810903089893.

[5] Bruneau, M., Chang, S. E., Eguchi, R. T., Lee, G. C., O’Rourke, T. D., Reinhorn, A. M., Shinozuka, M., Tierney, K., Wallace, W. A. and von Winterfeldt, D. (2003) "A framework to quantitatively assess and enhance the seismic resilience of communities", Earthquake spectra, Vol. 19, No. 4, pp. 733-752. ISSN 8755-2930. DOI 10.1193/1.1623497. 
[6] Das, H., Adamenko, T., Anaman, K., Gommes, R. and Johnson, G. (2003) "Agrometeorology related to extreme events", WMO. [Online]. Available: https://library.wmo.int/opac/doc_num. php?explnum_id=3442 [Accessed: 10 Dec. 2017].

[7] Davies, M., Béné, C., Arnall, A., Tanner, T., Newsham, A. and Coirolo, C. (2013) "Promoting resilient livelihoods through adaptive social protection: Lessons from 124 programmes in South Asia", Development Policy Review, Vol. 31, No. 1, pp. 27-58. E-ISSN 1467-7679. DOI 10.1111/j.1467-7679.2013.00600.x.

[8] De Haen, H. and Hemrich, G. (2007) "The economics of natural disasters: implications and challenges for food security", Agricultural Economics, Vol. 37, No. 1, pp. 31-45. E-ISSN 1574-0862. DOI 10.1111/j.1574-0862.2007.00233.x.

[9] Deaton, A. (1992) "Household saving in LDCs: Credit markets, insurance and welfare", The Scandinavian Journal of Economics, Vol. 94, No. 2, pp. 253-257. E-ISSN 1467-9442.

[10] Deaton, A. (1997) "The analysis of household surveys: a microeconometric approach to development policy", World Bank Publications, Vol. 1, 490 p. [Online]. Available: http://documents.worldbank. org/curated/en/593871468777303124/The-analysis-of-household-surveys-a-microeconometricapproach-to-development-policy [Accessed: 15 Dec. 2017].

[11] Fafchamps, M. (2009) "Vulnerability, risk management, and agricultural development", Center of Evaluation for Global Action. [Online]. Available: https://escholarship.org/uc/item/9752m723 [Accessed: 8 Jan. 2018].

[12] Fothergill, A. and Peek, L. A. (2004) "Poverty and disasters in the United States: A review of recent sociological findings", Natural hazards, Vol. 32, No. 1, pp. 89-110. E-ISSN 1573-0840, ISSN 0921-030X. DOI 10.1023/B:NHAZ.0000026792.76181.d9.

[13] Greiving, S., Fleischhauer, M. and Lückenkötter, J. (2006) "A methodology for an integrated risk assessment of spatially relevant hazards", Journal of environmental planning and management, Vol. 49, No. 1, pp. 1-19. DOI 10.1080/09640560500372800.

[14] IFRC/RCS (2003) “World Disasters Report: 2002”, Geneva, Switzerland: International Federation of Red Cross and Red Crescent Societies. [Online]. Available: http://www.ifrc.org/Global/ Publications/disasters/WDR/32600-WDR2002.pdf [Accessed: 10 Dec. 2017].

[15] Israel, D. C., and Briones, R. M. (2012) "Impacts of natural disasters on agriculture, food security, and natural resources and environment in the Philippines", PIDS discussion paper series (No. 2012-36).

[16] Jacoby, H. G. and Skoufias, E. (1997) "Risk, financial markets, and human capital in a developing country", The Review of Economic Studies, Vol. 64, No. 3, pp. 311-335. E-ISSN 1467-937X, ISSN 0034-6527. DOI 10.2307/2971716.

[17] Kaplan, D. (2010) "Natural disasters and differential household effects: Evidence from the May 2006 Java Earthquake", Unpublished manuscript.

[18] Kimball, M. S. (1990) "Precautionary saving and the marginal propensity to consume", NBER Working Paper No. 3403, NBER Program(s):Monetary Economics. DOI 10.3386/w3403.

[19] Loayza, N. V., Olaberria, E., Rigolini, J. and Christiaensen, L. (2012) "Natural disasters and growth: going beyond the averages", World Development, Vol. 40, No. 7, pp. 1317-1336. ISSN 0305-750X. DOI 10.1016/j.worlddev.2012.03.002.

[20] Long, F. (1978) "The impact of natural disasters on Third World agriculture: An exploratory survey of the need for some new dimensions in development planning", American Journal of Economics and Sociology, Vol. 37, No. 2, pp. 149-163. E-ISSN 1536-7150. DOI 10.1111/j.1536-7150.1978.tb02809.x.

[21] Ludwig, F., Van Scheltinga, C. T., Verhagen, J., Kruijt, B., van Ierland, E., Dellink, R., De Bruin, K., de Bruin, K. and Kabat, P. (2007) "Climate change impacts on Developing Countries-EU Accountability", European Parliament. [Online]. Available: http://www.europarl.europa.eu/RegData/ etudes/etudes/join/2007/393511/IPOL-ENVI_ET(2007)393511_EN.pdf [Accessed: 12 Jan. 2017]. 
[22] Markussen, T. (2015) “Land and land markets” in Tarp, F. „Growth, Structural Transformation and Rural Change in Viet Nam: A Rising Dragon on the Move“. [Online]. Available: https://www3. wider.unu.edu/sites/default/files/Events/PDF/VARHS\%20Report.pdf [Accessed: 20 Jan. 2017].

[23] Pelling, M., Özerdem, A. and Barakat, S. (2002) "The macro-economic impact of disasters", Progress in Development Studies, Vol. 2, No. 4, pp. 283-305. DOI 10.1191/1464993402ps042ra.

[24] Rose, A. (2004) "Defining and measuring economic resilience to disasters", Disaster Prevention and Management: An International Journal, Vol. 13, No. 4, pp. 307-314. ISSN 0965-3562. DOI 10.1108/09653560410556528.

[25] Rosenzweig, M. R. and Wolpin, K. I. (1993) "Credit market constraints, consumption smoothing, and the accumulation of durable production assets in low-income countries: Investments in bullocks in India", Journal of political economy, Vol. 101, No. 2, pp. 223-244. E-ISSN 1537-534X, ISSN 0022-3808.

[26] Sawada, Y. (2007) "The impact of natural and manmade disasters on household welfare", Agricultural Economics, Vol. 37, No. 1, pp. 59-73. E-ISSN 1574-0862. DOI 10.1111/j.1574-0862.2007.00235.x.

[27] Sivakumar, M. V. (2005) "Impacts of natural disasters in agriculture, rangeland and forestry: an overview”, in Sivakumar, M. V., Motha, R. P., Das, H. P. (eds) „,Natural Disasters and Extreme Events in Agriculture“, Springer, Berlin, Heidelberg. E-ISBN 978-3-540-28307-2, ISBN 978-3540-22490-7. DOI 10.1007/3-540-28307-2_1.

[28] Te'o, I. J. F. (1997) "The economic impact of natural disaters in the South Pacific", South Pacific Disater Reduction Programme, United Nations Department of Humannitarian Affairs and United Nations Department for Development Support and Management Services.

[29] Toya, H. and Skidmore, M. (2005) "Economic Development and the Impacts of Natural Disasters", Economics Letters, Vol. 94, No. 1, pp. 20-25. ISSN 0165-1765. DOI 10.1016/j.econlet.2006.06.020.

[30] Udry, C. (1994) "Risk and insurance in a rural credit market: An empirical investigation in northern Nigeria", The Review of Economic Studies, Vol. 61, No. 3, pp. 495-526. E-ISSN 1467-937X, ISSN 0034-6527. DOI 10.2307/2297901.

[31] Yu, B., Zhu, T., Breisinger, C., and Nguyen, H. M. (2010) "Impacts of climate change on agriculture and policy options for adaptation", No. 1015, IFPRI discussion papers, International Food Policy Research Institute (IFPRI). [Online]. Available: https://reliefweb.int/sites/reliefweb.int/files/ resources/A06030A0F205087E4925777C001E6988-Full_Report.pdf [Accessed: 20 Jan. 2017].

[32] Weber, S. (2010) "bacon: An effective way to detect outliers in multivariate data using Stata (and Mata)", Stata Journal, Vol. 10, No. 3, pp. 331-338. E-ISSN 1536-8634, ISSN 1536-867X.

[33] World Bank (2009) "Climate change and development", Washington DC.: The World Bank Group, 9 p., [Online]. Available: http://documents.worldbank.org/curated/en/185171468331853022/ Climate-change-and-development [Accessed: 23 Jan. 2017].

[34] Zeldes, S. P. (1989) "Optimal consumption with stochastic income: Deviations from certainty equivalence", The Quarterly Journal of Economics, Vol. 104, No. 2, pp. 275-298. E-ISSN 1531-4650, ISSN 0033-5533. DOI 10.2307/2937848. 